\title{
A spatiotemporal gradient in the anthropization of Pyrenean landscapes. Preliminary report
}

\author{
Valentí Rull ${ }^{1^{*}}$, Teresa Vegas-Vilarrúbia ${ }^{2}$ \\ ${ }^{1}$ Botanic Institute of Barcelona (CSIC), Pg. del Migdia s/n, 08038 Barcelona, Spain. Email: \\ vrull@csic.es \\ ${ }^{2}$ Department of Evolutionary Biology, Ecology and Environmental Sciences, University of \\ Barcelona, Av.Diagonal 643, 08028 Barcelona, Spain.Email: tvegas@ub.edu
}

\begin{abstract}
A preliminary analysis of the timing of landscape anthropization in the southern-central Pyrenees shows the occurrence of an elevational gradient from the Bronze Age (basal belts) to the Middle Ages (alpine belts). This relationship is statistically significant and suggests an average anthropization rate of $40 \mathrm{~m}$ in elevation per century. The elevational gradient is most clear between the Bronze Age and the Roman occupation, suggesting a progressive upward anthropization trend from the south with the likely involvement of Iberian cultures. During the Middle Ages, a massive anthropization pattern of subalpine/alpine areas is observed; this pattern is chronologically consistent with the incursion of northern cultures crossing the Pyrenees and the development of extensive high-mountain pastoralism and horizontal transhumance. In general, the progression of upward anthropization has occurred during warm climatic phases. Further work is needed to confirm these observations, especially in areas with few available paleoecological studies, notably the basal and montane belts. It could be interesting to develop similar studies of other Pyrenean regions and other mountain ranges.
\end{abstract}

Keywords: Lanscape anthropization, central Pyrenees, pollen analysis, elevational gradient 


\section{Introduction}

This brief communication explores the possibility of the progressive landscape anthropization with elevation (basimontane to alpine belts) and time (from the Bronze Age to the Middle Ages) in the central Pyrenees (Fig. 1). The study region is located on the southern slopes of the highest part of the Pyrenees, including areas of Spain and Andorra; however, the possibility of similar patterns in other Pyrenean areas and in other mountain ranges is suggested. It should be emphasized that this is not a study about the progressive human settlement of mountain environments that may have had little or no effect on the general configuration of mountain landscapes. This survey is concerned specifically with the large-scale and irreversible human transformations of original landscapes into anthropic landscapes that led to the present-day ecological configurations of different elevational belts. Settlement patterns are usually reconstructed using archaeological evidence, whereas landscape anthropization is inferred from paleoecological evidence, mainly palynological analyses of peat bogs and lake sediments. This paper briefly introduces previous reviews on the human settlement and landscape anthropization of the Pyrenees to finalize the already mentioned hypothesis of a potential chrono-elevational anthropization gradient and the dataset on which this possibility is based. The possible influence of climate change is also discussed, and some potential cultural implications of the recorded gradient are advanced.

\section{Previous studies}

Gassiot Ballbè et al. (2017) summarized the available archaeological evidence on the human settlement of the Pyrenees. According to these authors, human presence was very scarce during Late Glacial and Early Holocene times (19,000-8000 yr BP), likely due to harsh climatic conditions, and most human populations lived in low- to mid-elevation peripheral Pyrenean areas and in lower valleys within the mountain range. However, some human activity has been detected in subalpine and alpine areas during the Younger Dryas period. High-mountain environments began to be settled occasionally and/or temporarily in the Early-Mid Holocene (8000-6000 yr BP) by groups of Mesolithic hunter-gatherers. Neolithization had started by 5600-3000 yr BP, leading to the establishment of more stable settlements and the development of farming and pastoralism at low, middle and high elevations. A significant increase in the occupation of the area occurred between 3500 and $2500 \mathrm{yr} \mathrm{BP}$ (from the Bronze Age to the Iron Age), especially in areas above the present treeline, probably due to an increase in mobile herding practices.

Using paleoecological evidence-i.e., pollen-based vegetation reconstructions-from some sites in the eastern area of the central Pyrenees, Pèlachs et al. (2017) concluded that the starting point of modern farming and livestock-raising practices occurred at approximately $4250 \mathrm{yr} \mathrm{BP}$ and that the maximum human pressure, as manifested in the maximum magnitude of landscape opening by forest clearing, started in the Roman Period and persisted throughout the last two millennia. González-Sampériz et al. (2017) extended the dataset to the entire central Pyrenean area and included available paleoecological records from basimontane and montane belts. These authors concluded that although early signs of human impact were already visible in some sites by $4000 \mathrm{yr}$ BP (Bronze Age), it was not until Medieval times that human activities became especially important in terms of landscape anthropization, regardless of the elevations or the geographical locations of the sites considered. A general conclusion was that the development of the Pyrenean landscapes was mainly controlled by the climate until Medieval times, when humans took the lead (González-Sampériz et al., 2017). It is also noteworthy that, according to these authors, the environmental history of the central Pyrenees shows a relatively high degree of internal coherence across space and elevation. Using a similar dataset, with the addition of some archaeological sites and dated paleofire records, González-Sampériz et al. (2019) attempted to define the shaping of cultural 
landscapes-i.e., anthropogenic deforestation and the expansion of open vegetation-in the central Pyrenees in chronological terms. According to these authors, this method could be considered the most reliable procedure for determining the beginning of the Anthropocene in the study area. The conclusion was that in the central Pyrenees, general landscape anthropization did not begin some millennia ago but instead took place during recent centuries, starting in early Medieval times, at approximately 700 yr BP (1300 CE).

\section{The gradient hypothesis}

The idea of assumed geographical and elevational homogeneity in the ultimate anthropization of the Pyrenean landscapes is evident in the paleoecological reviews dealing with this topic discussed above, and the preferred time intervals during which these transformations are assumed to have happened are Late Roman and early Medieval times. However, a more detailed analysis of the chronological inferences of each original paper regarding the anthropization of each particular site reveals the occurrence of higher variability than was previously expected. The question here is whether this variability may have an elevational pattern, a possibility that has recently been suggested (Rull et al., 2021) but remains unexplored. This paper uses chronological data from the original references to preliminarily test this chrono-elevational hypothesis.

The dataset used in this study is similar to those provided by Pèlachs et al. (2017) and González-Sampériz et al. $(2017,2019)$; altogether, these datasets account for all paleoecological works developed to date in the southern-central Pyrenees. In this paper, however, only sites with reliable dating and continuous palynological records, including data of the last 3-4 millennia (since the Bronze Age), were considered. These sites are depicted in Fig. 1 , and the raw data utilized are provided in Table 1. A biplot of elevation versus anthropization time, as given in the original references, is displayed in Fig. 2. In one case (Rn), the anthropization date was not explicitly mentioned and was deduced from the dated pollen diagrams. In the other cases, ranges were provided for the anthropization time, and these ranges usually corresponded to the upper and lower boundaries of the pollen zone representing landscape anthropization. In these cases, the lower value of each range was considered.

Using this dataset, the obtained correlation between anthropization and elevation was evident and statistically significant $(r=0.698 ; p<0.001)$. The linear regression equation had a slope of 0.4 (Fig. 2), which may be interpreted as an average anthropization rate of $0.4 \mathrm{~m}$ in elevation per year (or $40 \mathrm{~m}$ per century). Whereas some cultural phases are relatively well represented, especially the Middle Ages, others show relevant information gaps; this is the case, for example, for the Roman period. Regarding the ecological belts, there is also a clear difference between the subalpine/alpine belts, which contain most of the available data, and the basal/montane belts, which have only 3-4 sites. The trend is clear for the basal (Bronze Age), montane (Iron Age to Roman Period) and alpine (Middle Ages) belts, but the subalpine belt shows significant anthropization dispersion encompassing the whole temporal range, from the Bronze Age to the Middle Ages. This high dispersion is mainly due to three sites (BN, CB and $\mathrm{BE}$ ) that were anthropized during the Bronze Age and the Iron Age, whereas the majority of the subalpine sites were anthropized in Medieval times. Without these three sites, the general correlation increases to $r=-0.820(p<0.001)$. The case of the early anthropization of the $\mathrm{BE}$ site, in comparison with other sites from the same valley situated at similar elevations (RO and OS), was discussed by Ejarque et al. (2010), who emphasized that the spatial fragmentation of the human use of mountain resources led to microscale variability in land use patterns. It is also possible that some sites were anthropized earlier than expected by the gradient model due to the occurrence of special resources available for exploitation that could have been absent at other sites. Examples could be water availability, mining or the exploitation of some subalpine forests for wood and/or charcoal. 
The possibility of other geographical gradients was also tested. There was no significant correlation between anthropization age and longitude $(R=0.008 ; p=0.927)$, which rules out a possible E-W or W-E component in the anthropization of the central Pyrenees. In contrast, the correlation with latitude was significant $(r=-0.485 ; p=0.025)$, which was likely due to the positive correlation between latitude and elevation $(r=0.436 ; p=0.048)$. Therefore, we can conclude that, with the available information, the most influential geographical parameter in the anthropization of the southern-central Pyrenees was elevation, and for this reason, anthropization progressed from south to north between the Bronze Age and the Middle Ages, when massive anthropization of the subalpine and alpine belts occurred. The elevational S-N trend suggests that before Medieval times, human pressures on Pyrenean landscapes were progressive and came mainly from the south, likely involving autochthonous Iberian cultures until Roman occupation occurred shortly before $2000 \mathrm{yr}$ BP. During the Middle Ages, the development of extensive pastoralism and horizontal transhumance in the highlands (GarcíaRuiz et al., 2020), as well as the Pyrenean penetration by and further establishment of the northern Carolingian Empire in the Iberian Peninsula in 800 CE (Rull \& Vegas-Vilarrúbia, 2015), may have changed the temporal and spatial anthropization trends, thus facilitating the almostsimultaneous anthropization of the subalpine and alpine belts (Fig. 2).

\section{Climatic influence}

To properly characterize the possible influence of climatic changes on anthropization, it would be necessary to know the detailed anthropization rates and their eventual variations over time in relation to known climatic phases. At the present stage, this is not possible due to insufficient data, and the analysis should instead proceed on a site-by-site basis. Overall, twothirds (14) of the studied sites were anthropized during warm climatic phases, and only onethird (seven) of the sites were anthropized during cold climatic phases. From the Bronze Age to Roman occupation, when the chrono-elevational gradient became more evident, most sites (five out of seven) were anthropized during warm phases (Fig. 2). During the Middle Ages, when the gradient was disrupted, ten of 14 sites were anthropized during warm periods. The whole picture suggests that, regardless of the particular trends of each cultural phase, relatively warmer climates facilitated the progressive occupation and anthropization of higher landscapes. These observations seem unsurprising, as a warming climate favors the upward displacement and settlement of human populations, but the progression of upward anthropization during cold phases, although more minor than that during warm phases, deserves some explanation. Interestingly, all sites that were anthropized during cold climates were lake catchments except one, which suggests that water availability favored human settlement despite the occurrence of cold climates. However, these are preliminary observations that should be confirmed with future studies that consider the local conditions of each particular site.

\section{Final remarks}

In addition to the well-known general intensification of human pressures on Pyrenean landscapes during the Middle Ages (Pèlachs et al., 2017; González-Sampériz et al., 2017, 2019; García Ruíz et al., 2020; Rull et al., 2021), the previous impressions of the general Pyrenean anthropization during Medieval times may be influenced by a sampling bias created by the dominance of subalpine and alpine localities whose landscapes were indeed irreversibly anthropized in the Middle Ages (Fig. 2). This is likely a consequence of the greater abundances of sedimentary archives (from glacial lakes and peat bogs) at high elevations, the occurrences of which are favored by fluvioglacial geomorphology and relatively colder climates in comparison with basal and montane belts, where these types of sedimentary bodies are scarcer. However, when the available quantitative data are combined, a different picture 
emerges in the form of a spatiotemporal pattern. The potential occurrence of a chronoelevational gradient in the anthropization of the southern-central Pyrenees is consistent with the currently available evidence but should still be considered a hypothesis to be confirmed with future studies, especially in the basal and montane belts where few studies are currently available. It is worth focusing efforts in this sense to test whether the proposed gradient is confirmed and, if so, to estimate its magnitude and potential cultural implications. It would also be interesting to verify the occurrence of the same or other geographical patterns in the anthropization of the northern slopes of the Pyrenees, where the elevational gradient is inversed, and on other mountain ranges, where the relationships between elevation and latitude/longitude are different from those of the Pyrenees. An analysis of this type would help clarify when and how (and, hopefully, by whom) mountain landscapes have been irreversibly anthropized until giving rise to the present situation.

\section{Acknowledgements}

This work was supported by the Ministry of Science, Innovation and Universities (grant CGL2012-3665), and the Autonomous Organism of National Parks (grant OAPN-24505). 


\section{References}

Büntgen, U., Myglan, V.S., Charpentier, F., et al. 2016. Cooling and societal change during the Late Antique Little Icea Age from 536 to around 660 AD. Nature Geoscience 9, 231-236.

Catalan, J., Pérez-Obiol, R., Pla, S. 2000. Canvis Climàtics a Aigüestortes durant els darrers 15.000 anys. V Jornades Sobre Recerca al Parc Nacional d'Aigüestortes i Estany de Sant Maurici, Espot, pp. 45-52.

Catalan, J., Pèlachs, A., Gassiot, E., et al. 2013. Interacción entre clima y ocupación humana en la configuración del paisaje vegetal del Parque Nacional de Aigüestortes i Estany de Sant maurici a lo largo de los últimos 15.000 años. Proyectos de Investigación en Parques Nacionales: 2009-2012, OPAN, Madrid, pp. 71-92.

Catalan, J., Pla-Rabés, S., García, J., et al. 2014. Air temperatures-driven $\mathrm{CO}_{2}$ consumption by rock weathering at short timescales: Evidence from a Holocene lake sediment record. Geochimica et Cosmochimica Acta 136, 67-79.

Cunill, R., Soriano, J.M., Bal, M.C., et al. 2013. Holocene high-altitude vegetation dynamics in the Pyrenees: A pedoanthracology contribution to an interdisciplinary approach. Quaternary International 289, 60-70.

Ejarque, A. 2009. Génesis y configuración microregional de un paisaje cultural pirenaico de alta montaña durante el Holoceno: estudio polínico y de otros indicadores paleoambientales en el Valle del Madriu-Perafita-Claror (Andorra). PhD dissertation, Universitat Rovira i Virgili, Tarragona.

Ejarque, A., Julià, R., Riera, S., et al. 2009. Tracing the history of highland human management in the eastern pre-Pyrenees: an interdisciplinary palaeoenvironmental study at the Pradell fen, Spain. Holocene 19, 1241-1255.

Ejarque, A., Miras, Y., Riera, S., et al. 2010. Testing micro-regional variability in the Holocene shaping of high mountain cultural landscapes: a palaeoenvironmental case-study in the eastern Pyrenees. Journal of Archaeological Science 37, 1468-1479.

Garcés-Pastor, S., Cañellas-Boltà, N., Clavaguera, A., et al. 2016. Vegetation shifts, human impact and peat bog development in Bassa Nera pond (Central Pyrenees) during the last millennium. Holocene 27, 553-565.

Garcés-Pastor, S., Cañellas-Boltà, N., Pèlachs, A., et al. 2017. Environmental history and vegetation dynamics in response to climate variations and human pressure during the Holocene in Bassa Nera, Central Pyrenees. Palaeogeography, Palaeoclimatology, Palaeoecology 479, 48-60.

García-Ruiz, J.M., Tomás-Faci, G., Diarte-Blasco, P., et al. 2020. Transhumance and long-term deforestation in the subalpine belt of the central Spanish Pyrenees: An interdisciplinary approach. Catena 195, 104744.

Gassiot Ballbè, E., Mazzuco, N., Clemente Conte, I., et al. 2017. The beginning of high mountain occupations in the Pyrenees. Human settlements and mobility from 18,000 cal BC to 2000 cal BC. In: Catalan, J., Ninot, J.M., Aniz, M.M. (eds.), High Mountain Conservation in a Changing World. Springer, Cham, pp. 78-105.

González-Sampériz, P., Aranbarri, J., Pérez-Sanz, A., et al. 2017. Environmental and climate change in the southern Central Pyrenees since the Last Glacial Maximum: A review from the lake records. Catena 149, 668-688.

González-Sampériz, P., Montes, L., Aranbarri, J., et al. 2019. Escenarios, tiempo e indicadores paleoambientales para la identificación del Antropoceno en el paisaje vegetal del Pirineo Central (NE Iberia). Cuadernos de Investigación Geográfica 45, 167-193.

Gribbin, J., Lamb, H.H. 1978. Climatic change in historical times. In: Gribbin, J. (ed.), Climatic Change. Cambridge University Press, Cambridge, pp. 68-82.

Helama, S., Jones, P.D., Briffa, K.R. 2017. Dark Ages Cold Period: a literature review and directions for future research. Holocene 27, 1600-1606. 
Leunda, M., González-Sampériz, P., Gil-Romera, G., et al. 2017. The Late-Glacial and Holocene Marboré Lake sequence (2612 m a.s.l., Central Pyrenees, Spain): Testing high altitude sites sensitivity to millennial scale vegetation and climate variability. Global and Planetary Change 15, 214-231.

Mann, M.E., Zhang, Z., Rutherford, S., et al. 2009. Global signatures and dynamic origins of the Little Ice Age and the Medieval Climate Anomaly. Science 326, 1256-1260.

Martín-Chivelet, J., Muñoz-García, M.B., Edwards, R.L., et al. 2011. Land surface temperature changes in Northen Iberia since $4000 \mathrm{yr} \mathrm{BP}$, based on $\delta^{13} \mathrm{C}$ of speleothems. Global and Planetary Change 77, 1-12.

Martín-Puertas, C., Valero-Garcés, B., Brauer, A., et al. 2009. The Iberian-Roman Humid Period (2600-1600 cal yr BP) in the Zoñar Lake varve record (Andalucía, southern Spain). Quaternary Research 71, 108-120.

Miras, Y., Ejarque, A., Riera, S., et al. 2007. Dynamique holocène de la végétation et occupation des Pyrénées andorranes depuis le Néolithique ancien, d'après l'analyse pollinique de la tourbière de Bosc dels Estanyons ( $2180 \mathrm{~m}$, Vall de Madriu, Andorre). Comptes Rendus Palevol 6, 291-300.

Miras, Y., Ejarque, A., Riera, S., et al. 2015. Andorran high Pyrenees (Perafita Valley, Andorra): Serra Mitjana fen. Grana 54, 313-316.

Montserrat Martí, J.M. 1992. Evolución Glaciar y Postglaciar del Clima y la Vegetación en la Vertiente Sur del Pirineo: Estudio Palinológico. Monografías del Instituto Pirenaico de Ecología (CSIC) 6, 1-147.

Pèlachs, A., Soriano, J.M., Nadal, J., et al. 2007. Holocene environmental history and human impact in the Pyrenees. Contributions to Science 3, 421-429.

Pèlachs, A., Pérez-Obiol, R., Ninyerola, M., et al. 2009. Landscape dynamics of Abies and Fagus in the southern Pyrenees during the last 2200 years as a result of anthropogenic impacts. Review of Palaeobotany and Palynology 156, 337-349.

Pèlachs, A., Pérez-Obiol, R., Soriano, J.M., et al. 2017. The role of environmental geohistory in high-mountain landscape conservation. In: Catalan, J., Ninot, J.M., Aniz, M.M. (eds.), High Mountain Conservation in a Changing World. Springer, Cham, pp. 107-129.

Pérez-Sanz, A., González-Sampériz, P., Moreno, A., et al. 2013. Holocene climate variability, vegetation dynamics and fire regime in the central Pyrenees: the Basa de la Mora sequence (NE Spain). Quaternary Science reviews 73, 149-169.

$\mathrm{Pla}$, S., Catalan, J. 2004. Chrysophyte cysts from lake sediments reveal the submillennial winter/spring climate variability in the northwestern Mediterranean region throughout the Holocene. Climate Dynamics 24, 263-278.

Riera, S., Wansard, G., Julià, R. 2004. 2000-year environmental history of a karstic lake in the Mediterranean Pre-Pyrenees: the estanya lakes (Spain). Catena 55, 293-324.

Rull, V., Vegas-Vilarrúbia, T. 2015. Crops and weeds from the Lake Montcortès region (southern Pyrenees) during the last millennium: a comparison of historical and palynological records. Vegetation History and Archaeobotany 24, 699-710.

Rull, V., González-Sampériz, P., Corella, J.P., et al. 2011. Vegetation changes in the southern Pyrenean flank during the last millennium in relation to climate and human activities: the Montcortès lacustrine record. Journal of Paleolimnology 46, 387-404.

Rull, V., Vegas-Vilarrúbia, T., Corella, J.P., et al. 2021. Bronze Age to Medieval vegetation dynamics and landscape anthropization in the central pre-Pyrenees. Research Square Preprints, doi 10.20203/rs.3.rs-142567/v2. 
Table 1. Raw data used in this paper to analyze the relationship between elevation and anthropization time, as depicted in Fig. 1. The anthropization time and the corresponding palynological evidence were taken directly from the original references. Abbreviations: $L=$ Lake, $\mathrm{P}=$ Pond, $\mathrm{B}=\mathrm{Bog}$.

\begin{tabular}{|c|c|c|c|c|c|c|c|}
\hline Site & Code & $\begin{array}{l}\text { Elevation } \\
(\mathrm{m})\end{array}$ & Latitude & Longitude & $\begin{array}{l}\text { Anthropization } \\
\text { yr BP (CE/BCE) }\end{array}$ & $\begin{array}{l}\text { Palynological } \\
\text { evidence }\end{array}$ & References \\
\hline Marboré (L) & $\mathrm{Mb}$ & 2612 & 42.695631 & 0.040019 & $1300(650)$ & $\begin{array}{l}\text { Forest (especially } \\
\text { deciduous) reduction, } \\
\text { alpine meadows } \\
\text { expansion }\end{array}$ & $\begin{array}{l}\text { Leunda et al. } \\
\text { (2017) }\end{array}$ \\
\hline Forcat (L) & $\mathrm{Ft}$ & 2531 & 42.493889 & 1.639167 & $1150(800)$ & $\begin{array}{l}\text { Generalized } \\
\text { landscape opening } \\
\text { and grazing }\end{array}$ & Ejarque (2009) \\
\hline $\begin{array}{l}\text { Estany Blau } \\
\text { (L) }\end{array}$ & EB & 2471 & 42.496389 & 1.620833 & $1150(800)$ & $\begin{array}{l}\text { Generalized } \\
\text { landscape opening } \\
\text { and grazing }\end{array}$ & Ejarque (2009) \\
\hline $\begin{array}{l}\text { Serra Mitjana } \\
\text { (B) }\end{array}$ & SM & 2406 & 42.4645 & 1.582778 & 850 (1100) & $\begin{array}{l}\text { Woodland clearance } \\
\text { (fire) and grassland } \\
\text { expansion, grazing }\end{array}$ & $\begin{array}{l}\text { Miras et al. } \\
(2015)\end{array}$ \\
\hline $\begin{array}{l}\text { Riu dels Orris } \\
\text { (B) }\end{array}$ & $\mathrm{RO}$ & 2390 & 42.488889 & 1.637222 & $1100(850)$ & $\begin{array}{l}\text { Woodland retreat } \\
\text { and extension of } \\
\text { alpine grasslands, } \\
\text { grazing }\end{array}$ & $\begin{array}{l}\text { Ejarque et al. } \\
(2010)\end{array}$ \\
\hline $\begin{array}{l}\text { Orris de Setut } \\
\text { (B) }\end{array}$ & OS & 2300 & 42.4825 & 1.650278 & $1100(850)$ & $\begin{array}{l}\text { Woodland retreat } \\
\text { and extension of } \\
\text { alpine grasslands, } \\
\text { grazing }\end{array}$ & $\begin{array}{l}\text { Ejarque et al. } \\
(2010)\end{array}$ \\
\hline Estanilles (B) & Et & 2247 & 42.626149 & 1.29625 & $550(1400)$ & $\begin{array}{l}\text { Treeline lowering } \\
\text { (fire), pasture } \\
\text { development }\end{array}$ & $\begin{array}{l}\text { Cunill et al. } \\
(2013)\end{array}$ \\
\hline Redon (L) & $\mathrm{Rn}$ & 2240 & 42.640483 & 0.778297 & $1000(950)$ & $\begin{array}{l}\text { Forest retreat, } \\
\text { agropastoralism } \\
\text { increase }\end{array}$ & $\begin{array}{l}\text { Pla \& Catalan } \\
\text { (2004); Catalan } \\
\text { et al. (2014) }\end{array}$ \\
\hline $\begin{array}{l}\text { Planells de } \\
\text { Perafita (B) }\end{array}$ & PP & 2240 & 42.479167 & 1.566944 & $1150(800)$ & $\begin{array}{l}\text { Generalized } \\
\text { landscape opening } \\
\text { and grazing }\end{array}$ & Ejarque (2009) \\
\hline $\begin{array}{l}\text { Bosc del } \\
\text { Estanyons (B) }\end{array}$ & $\mathrm{BE}$ & 2180 & 42.480278 & 1.619167 & $2050(-100)$ & $\begin{array}{l}\text { Large-scale forest } \\
\text { opening, } \\
\text { agropastoralism, } \\
\text { metallurgy(?) }\end{array}$ & $\begin{array}{l}\text { Miras et al. } \\
\text { (2007); Ejarque } \\
\text { et al. (2010) }\end{array}$ \\
\hline Redó (L) & $\mathrm{Rd}$ & 2116 & 42.580039 & 0.958333 & $850(1100)$ & $\begin{array}{l}\text { General } \\
\text { deforestation, grazing } \\
\text { and cereal croppping }\end{array}$ & $\begin{array}{l}\text { Catalan et al. } \\
(2000,2013)\end{array}$ \\
\hline $\begin{array}{l}\text { Ibón de las } \\
\text { Ranas (L) }\end{array}$ & $\mathrm{IR}$ & 2092 & 42.794075 & -0.291636 & 700 (1250) & $\begin{array}{l}\text { Subalpine } \\
\text { deforestation, } \\
\text { pasture expansion }\end{array}$ & $\begin{array}{l}\text { Montserrat } \\
\text { Martí (1992) }\end{array}$ \\
\hline Pradell (B) & $\mathrm{Pd}$ & 1975 & 42.288889 & 1.547778 & $1100(850)$ & $\begin{array}{l}\text { Woodland } \\
\text { management (fire), } \\
\text { cropping, grazing }\end{array}$ & $\begin{array}{l}\text { Ejarque et al. } \\
(2009)\end{array}$ \\
\hline $\begin{array}{l}\text { Basa de la } \\
\text { Mora (L) }\end{array}$ & BM & 1914 & 42.546111 & 0.325 & 700 (1250) & $\begin{array}{l}\text { Deforestation and } \\
\text { expansion of grazing } \\
\text { lands }\end{array}$ & $\begin{array}{l}\text { Pérez-Sanz et al. } \\
\text { (2013) }\end{array}$ \\
\hline $\begin{array}{l}\text { Bassa Nera } \\
\text { (P) }\end{array}$ & $\mathrm{BN}$ & 1891 & 42.638472 & 0.924333 & $3150(-1200)$ & $\begin{array}{l}\text { Forest clearing (fires) } \\
\text { and intensification of } \\
\text { agropastoral } \\
\text { activities }\end{array}$ & $\begin{array}{l}\text { Garcés-Pastor } \\
\text { et al. (2016, } \\
\text { 2017) }\end{array}$ \\
\hline $\begin{array}{l}\text { Coma de Burg } \\
\text { (L) }\end{array}$ & $\mathrm{CB}$ & 1821 & 42.505 & 1.306111 & $2800(-850)$ & $\begin{array}{l}\text { Replacement of fir by } \\
\text { pine forests }\end{array}$ & $\begin{array}{l}\text { Pèlachs et al. } \\
(2007)\end{array}$ \\
\hline $\begin{array}{l}\text { Tramacastilla } \\
(\mathrm{L})\end{array}$ & $\mathrm{Tm}$ & 1668 & 42.724517 & -0.367869 & $1000(950)$ & $\begin{array}{l}\text { Forest clearing with } \\
\text { no recovery }\end{array}$ & $\begin{array}{l}\text { Montserrat- } \\
\text { Martí (1992) }\end{array}$ \\
\hline Llebreta (L) & $\mathrm{LI}$ & 1619 & 42.594444 & 0.888611 & $2100(-150)$ & $\begin{array}{l}\text { Treeline lowering, } \\
\text { expansion of alpine } \\
\text { meadows, cereal } \\
\text { cultivation }\end{array}$ & $\begin{array}{l}\text { Catalan et al. } \\
(2013)\end{array}$ \\
\hline $\begin{array}{l}\text { Prats de Vila } \\
\text { (B) }\end{array}$ & PV & 1150 & 42.638056 & 1.103611 & $2000(-50)$ & $\begin{array}{l}\text { Abies-Fagus } \\
\text { replacement, grazing }\end{array}$ & $\begin{array}{l}\text { Pèlachs et al. } \\
(2009)\end{array}$ \\
\hline
\end{tabular}




\begin{tabular}{|l|l|l|l|l|l|l|l|}
\hline & & & & & & $\begin{array}{l}\text { and agriculture } \\
\text { expansion }\end{array}$ & \\
\hline $\begin{array}{l}\text { Montcortès } \\
\text { (L) }\end{array}$ & Mt & 1027 & 42.330556 & 0.994722 & 2700 (-750) & $\begin{array}{l}\text { Deforestation (fire), } \\
\text { grazing and cropping }\end{array}$ & $\begin{array}{l}\text { Rull et al. (2011, } \\
\text { 2021), Rull \& } \\
\text { Vegas-Vilarrúbia } \\
\text { (2015) }\end{array}$ \\
\hline Estanya (L) & Es & 670 & 42.029706 & 0.527314 & $3700(-1750)$ & $\begin{array}{l}\text { Deforestation, cereal } \\
\text { cultivation }\end{array}$ & $\begin{array}{l}\text { Riera et al. } \\
\text { (2004); } \\
\text { González- } \\
\text { Sampériz et al. } \\
\text { (2017) }\end{array}$ \\
\hline
\end{tabular}


Figure 1. General map. A) Location of the Pyrenees (yellow box) with respect to the Iberian Peninsula. B) Closer view of the Pyrenees showing the study area (black box). C) Google Earth close-up of the study area showing the lakes and peat bogs considered in this work (red dots). The abbreviations correspond to those described in Table 1.

Figure 2. Relationship between time and landscape anthropization in the studied region according to the original information from the literature provided in Table 1. White dots represent lakes, and blue dots are peat bogs. The green arrow indicates the Pyrenean penetration by and further establishment of the Carolingian Empire on the Iberian Peninsula. Gray bands indicate cold climatic phases. Abbreviations: BAWP = Bronze Age Warm Period, $\mathrm{IACP}=$ Iron Age Cold Period, RWP = Roman Warm Period, DACP = Dark Ages Cold Period, MCA $=$ Medieval Climate Anomaly, LIA = Little Ice Age, IRHP = Iberian-Roman Humid Period. The climatic phases correspond to those described by Gribbin \& Lamb (1978), Mann et al. (2009), Martín-Puertas et al. (2009), Martín-Chivelet et al. (2011), Büntgen et al. (2016) and Helama et al. (2017). 


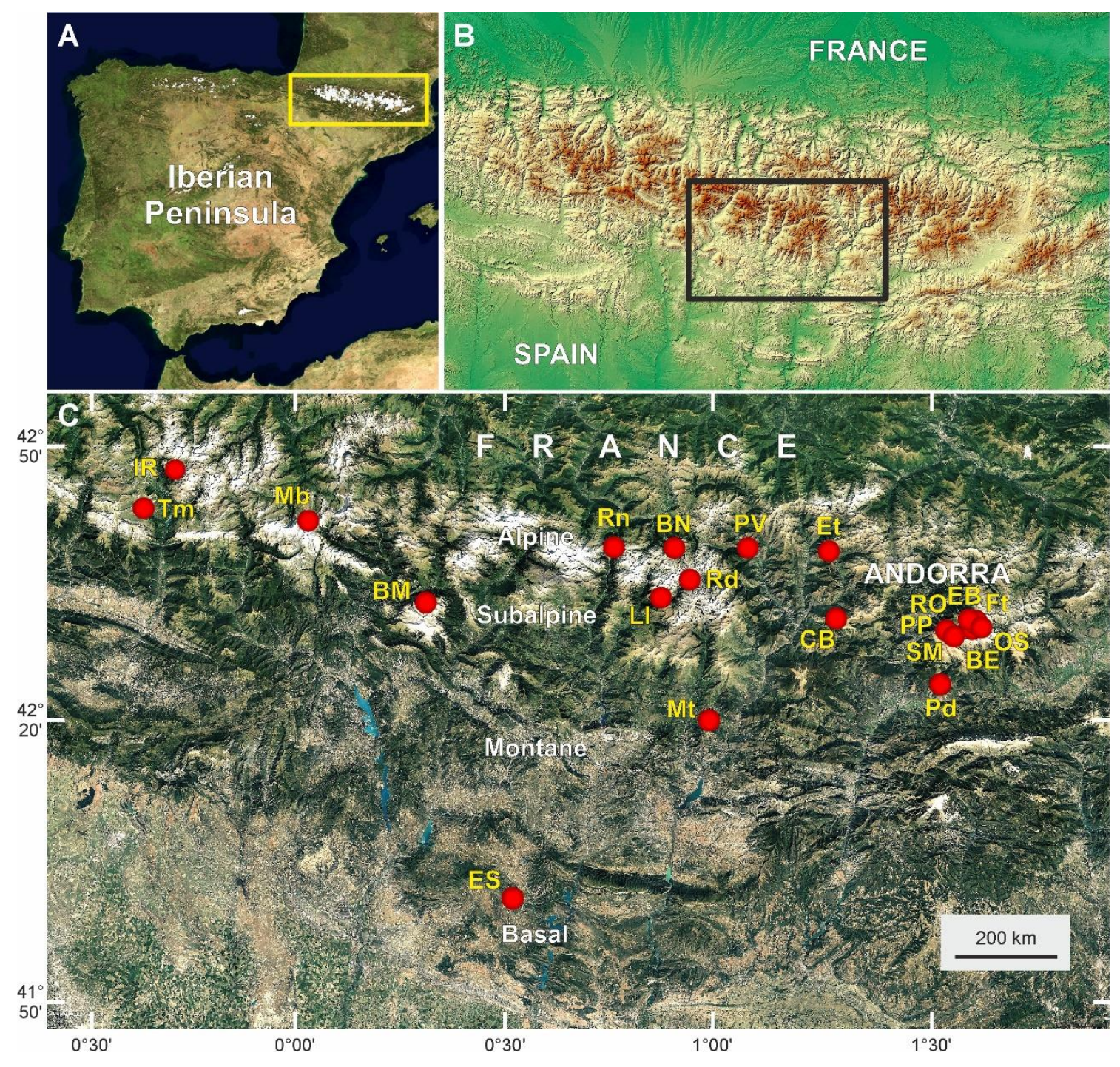

Figure 1 


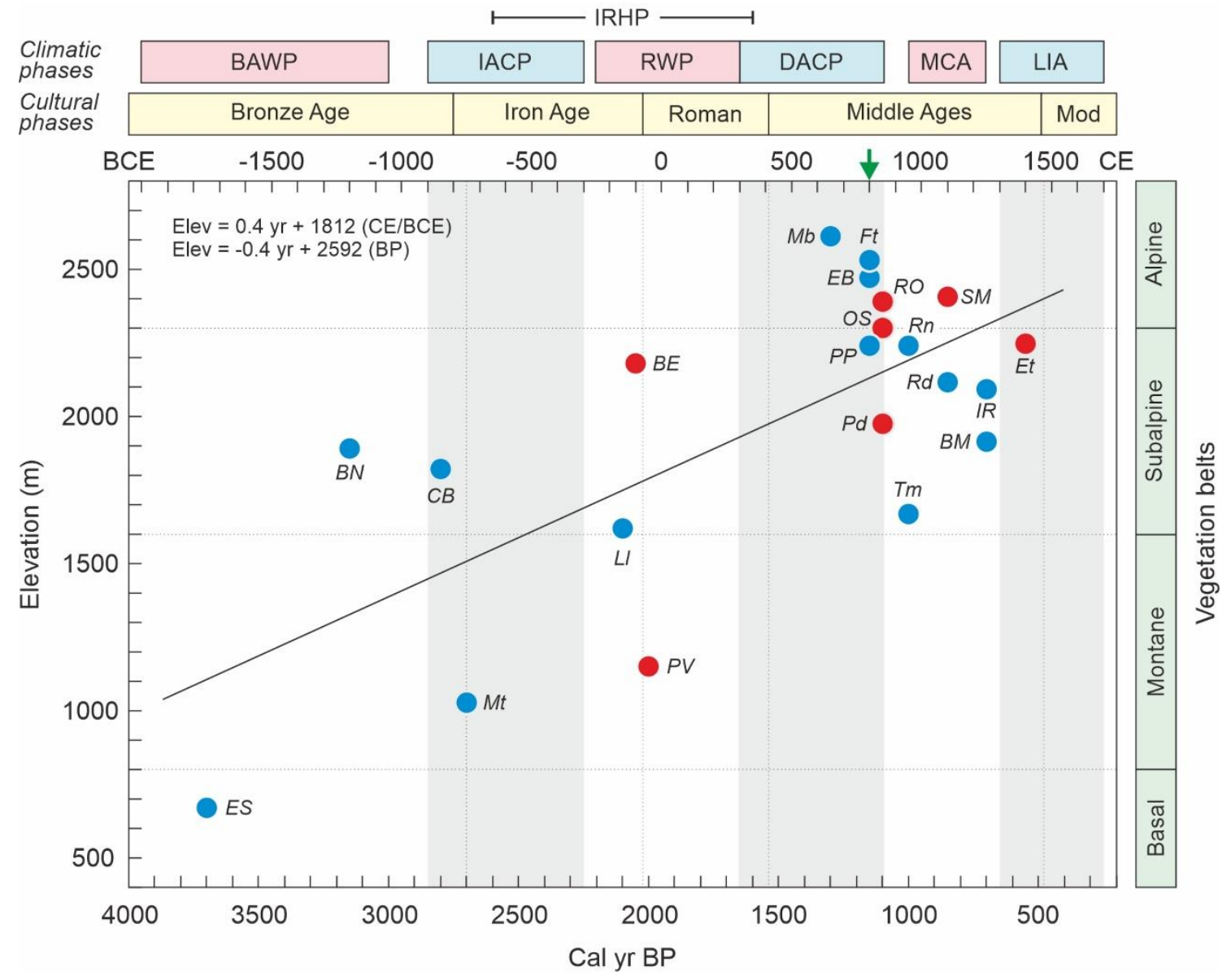

Figure 2 